\title{
The IODP Expedition 332 : Eyes on the Prism, The NanTroSEIZE Observatories
}

\section{Abstract}

The Nankai Trough Seismogenic Zone Experiment (NanTroSEIZE) is a major long-term drilling project designed to investigate the seismogenic behavior of subduction zone plate boundaries. Integrated Ocean Drilling Program (IODP) Expedition 332 deployed a long-term borehole monitoring system (LTBMS), an advanced Circulation Obviation Retrofit Kit (CORK)-type observatory. The recovery of pressure and temperature data from a temporary observatory (SmartPlug) deployed during IODP Expedition 319 helped prove the SmartPlug concept. The permanent LTBMS was deployed $n$ the upper $1000 \mathrm{~m}$ of Site C0002, while the SmartPlug was recovered from Site C0010 and replaced with a more capable "GeniusPlug", incorporating an extension with a geochem-ical sampler and biological experiment to the original SmartPlug design. SmartPlug pressure and temperature data showed signs of transient pressure events.

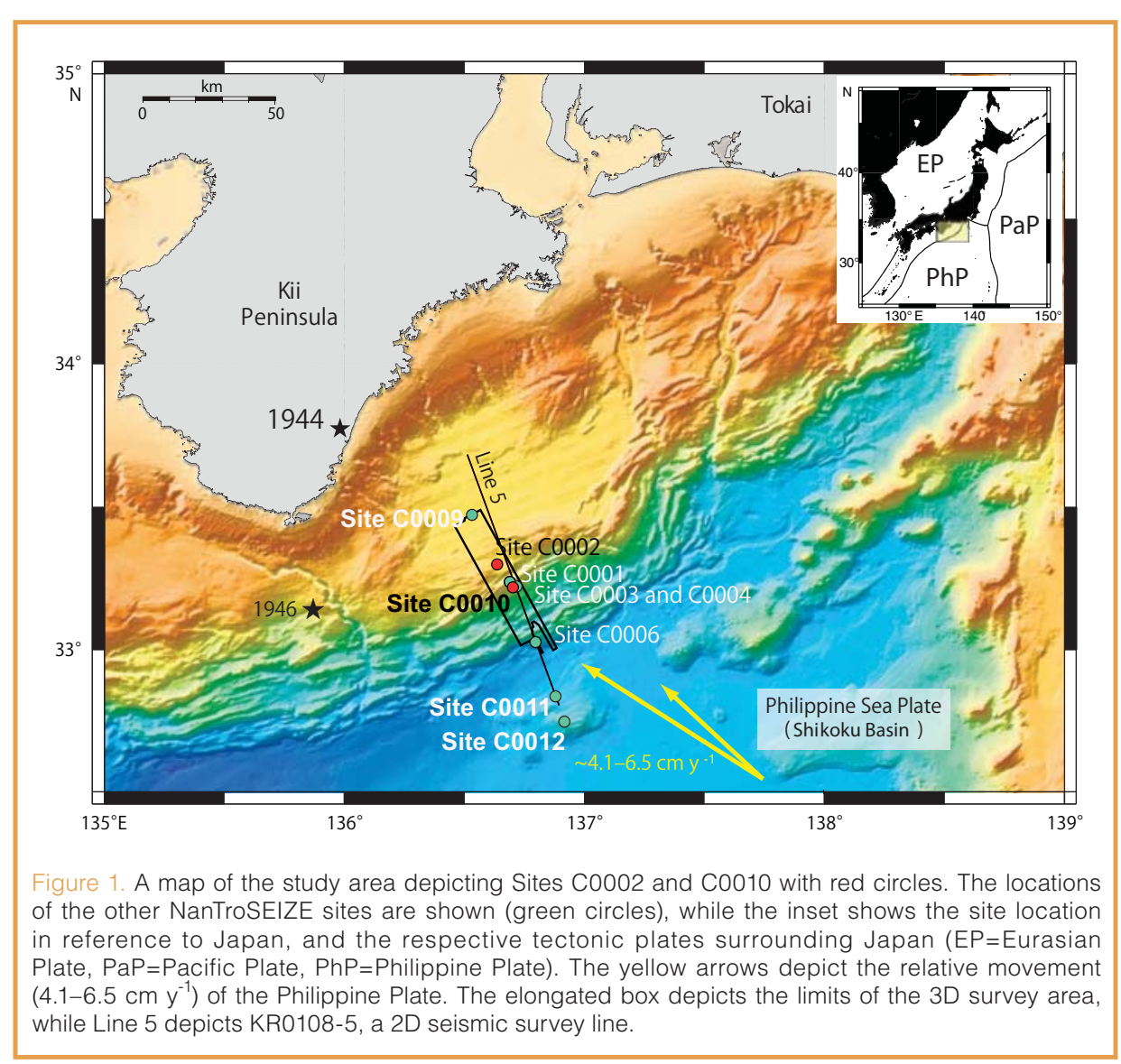

\section{Introduction}

Subduction zones account for the majority of global seismic moment release, and slip along subduction megathrusts generate both damaging earthquakes and tsunamis. Understanding the processes that govern the distribution, mechanics, and style of slip along subduction and other plate boundary fault systems is essential to earthquake and tsunami hazard assessment. NanTroSEIZE is a multi-expedition, multistage IODP drilling project focused on understanding the mechanics of subduction plate boundary faults (Tobin and Kinoshita, 2006). The drilling program includes a coordinated effort to characterize, sample, and instrument the plate boundary system at several locations offshore of the Kii Peninsula (Fig. 1), culminating in drilling, sampling, and instrumenting the plate boundary fault system near the updip limit of inferred coseismic slip, at 5 7 km below sea-floor (Fig. 2; Tobin and Kinoshita, 2006) and in installation of a distributed network of integrated borehole observatories to monitor strain and seismological, thermal, and hydrological processes.

In the NanTroSEIZE study area, high-resolution seismic reflection profiles across the outer rise clearly document a major out-of-sequence thrust fault system (megasplay fault, after Park et al., 2002) that branches from the décollement close to the updip limit of inferred coseismic rupture in the 1944 Tonankai M 8.2 earthquake (Fig. 2). Several lines of evidence indicate that the megasplay system is active, may accommodate a significant fraction of plate boundary motion, and may slip coseismically (Moore et al., 2007; Strasser et al., 2009). However, the partitioning of strain between the lower plate interface (the décollement zone) and the megasplay system and the nature and mechanisms of fault slip as a function of depth and time on the megasplay are not understood. Thus, the meg- 


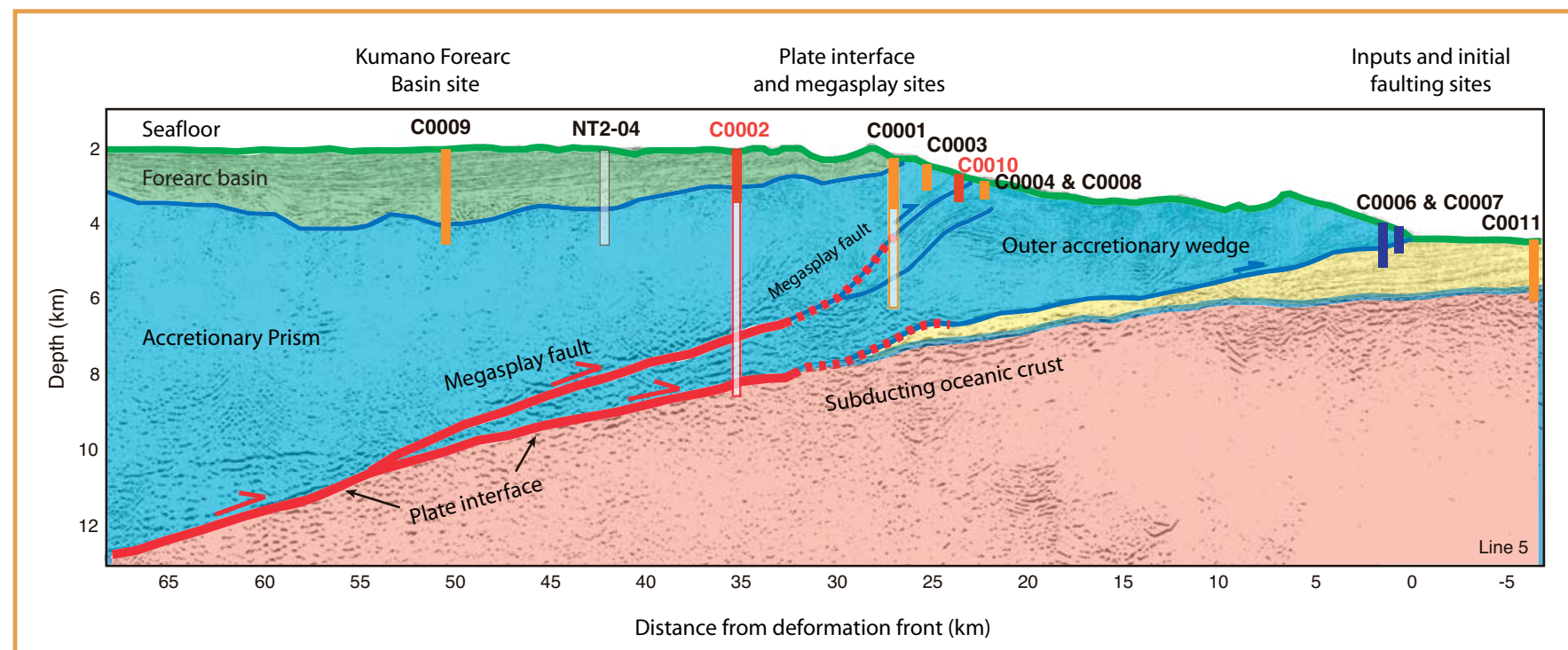

Figure 2. Interpreted seismic profile at regional scale showing interpretation by Park et al. (2002) and NanTroSEIZE drill sites. Sites C0002 and C0010 are indicated in red. All drill sites show current penetration (solid bars) and planned penetration (empty bars).

asplay and the region near its updip terminus comprise one of the primary drilling and monitoring targets for NanTroSEIZE.

NanTroSEIZE Stage 1 included riserless drilling along a transect of eight sites that targeted the frontal thrust region near the trench, the megasplay fault region, and the Kumano forearc basin region (Fig. 2) One of these sites, IODP Site $\mathrm{C} 0002$ in the forearc basin, also serves as the ultra-deep riser-drilling target. Expedition 319 installed a temporary borehole observatory (SmartPlug) at Site C0010 in an interval of screened casing across the megasplay fault (McNeill et al., 2010; Saffer et al., 2010).

IODP Expedition 332 continued, expanded, and extended the observatory program, installing the LTBMS and GeniusPlug observatories at Sites C0002 and C0010, respectively.

\section{The Nankai Margin}

The Nankai Trough (Fig. 1) is formed by subduction of the Philippine Sea Plate underneath southwestern Japan at a rate of $\sim 4.1-6.5 \mathrm{~cm} \mathrm{y}^{-1}$ along an azimuth of $300^{\circ}-315^{\circ} \mathrm{N}$ (Seno et al., 1993; Miyazaki and Heki, 2001) down an interface dipping $3^{\circ}-7^{\circ}$ (Kodaira et al., 2000). The Nankai Trough subduction zone forms a sediment-dominated accretionary prism. In the toe region, an incoming sedimentary section $\sim 1-1.5 \mathrm{~km}$ thick is accreted to or underthrust below the margin (Moore et al., 2001, 2009).

The megasplay is a major structural boundary to the rear of the accretionary wedge; it forms the boundary between the outer wedge and forearc basin, traverses the entire wedge, and has had a protracted history as shown by the tilted forearc basin sediments trapped behind its leading edge (Moore et al., 2007). The megasplay is also hypothesized to represent a discontinuity in rock physical properties and a mechanical boundary between the inner and outer accretionary wedge and between aseismic and seismogenic fault behavior along the plate boundary (Wang and $\mathrm{Hu}, 2006$ ). At depth, the megasplay is imaged in seismic reflection data as a high-amplitude reflector (Fig. 2; Bangs et al., 2009), and it branches into a family of smaller splays in the upper few kilo-

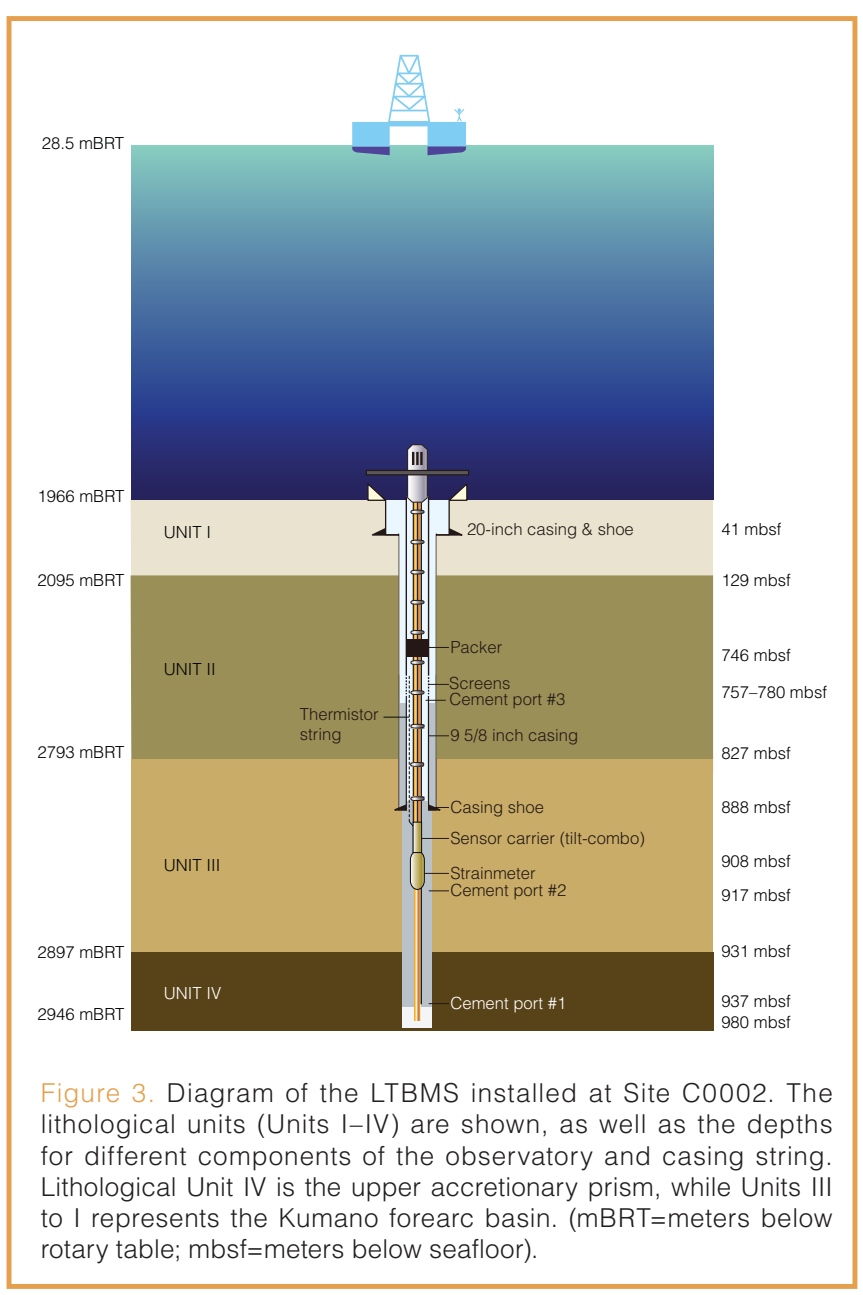


meters below the seafloor, including the fault penetrated at IODP Sites C0004 and C0010. Direct fault intersections to the seafloor are not observed (Moore et al., 2007; Strasser et al., 2009); however, the thrust sheets wedge into these deposits, causing tilt and slumping of even the deposits nearest to the surface. Evidence for mass wasting complexes is consequently found at IODP Sites C0004, C0008, and C0010. Site C0010, as well as Site C0002 further landward in the forearc basin, were the target areas of Expedition 332 .

Site C0010, drilled during Expedition 319 (McNeill et al., 2010; Saffer et al., 2010) included Logging While Drilling (LWD) drilling through the megasplay fault zone and into its footwall, setting casing with screens across the fault zone, and installing a simple and temporary borehole observatory (SmartPlug) to monitor fluid pressure and temperature in the shallow megasplay. Major lithologic boundaries as well as the location of the megasplay fault at $\sim 407$ mbsf were identified in LWD data and were used to select a depth interval spanning the fault for placement of the two screened casing joints (Saffer et al., 2010).

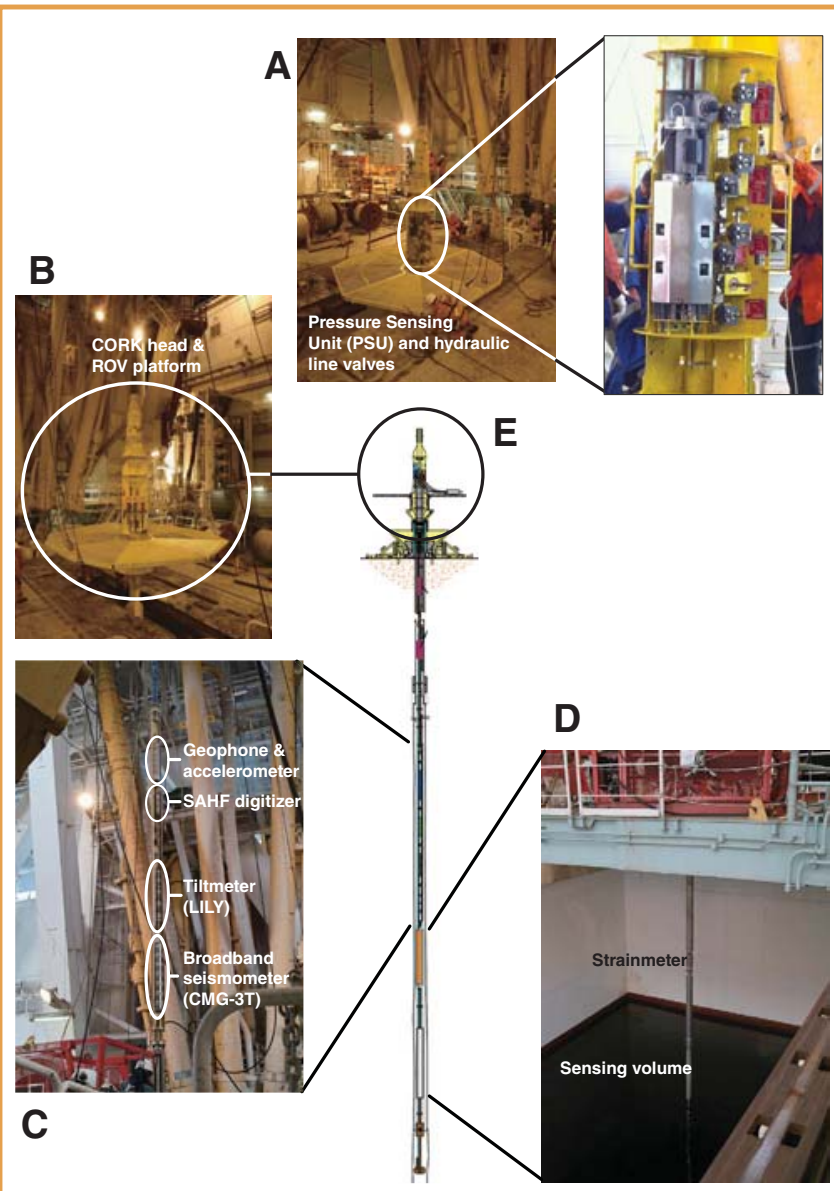

Figure 4. The sensors and placement on the LTBMS CORK observatory at Site C0002. Photos of the different sensor packages and their arrangement on the downhole and CORK head sections were taken during deployment. [A] The Pressure Sensing Unit (PSU), an independent sensor array mounted on the CORK head. [B] CORK head and ROV platform. [C] Sensor carrier, with a geophone and accelerometer assembly, a stand-alone heat flow meter (SAHF) digitizer for the thermistor string, a LILY tiltmeter, and a CMG-3T Guralp seismometer. [D] Strainmeter and sensing volume. [E] Diagram of the Site C0002 CORK observatory.
Site $\mathrm{C} 0002$ is located near the southeastern edge of the Kumano forearc basin (Fig. 2). Expedition 332 revisited Site $\mathrm{C} 0002$ and drilled with a limited suite of LWD/measurement-while-drilling (MWD) tools for reconnaissance and to identify the most suitable depth intervals to place the sensors of the LTBMS.

\section{NanTroSEIZE Observatories and IODP Expedition 332}

Expedition 332 operations at Site C0010 involved recovering the SmartPlug installed during Expedition 319 and replacing it with an expanded GeniusPlug Observatory. Operations at Site C0002 were the first steps in one of the two final phases of NanTroSEIZE, in this case, installing a permanent observatory in the upper section of the Kumano Basin, which will in the future have a complementary deep observatory installed down to the plate boundary.

\section{LTBMS Sensors, Site C0002}

The LTBMS sensor array (Fig. 3) is designed to collect multiparameter observations covering a dynamic range of events, including local microearthquakes, low frequency earthquakes, and large-scale earthquakes related to the Tonankai plate boundary movement approximately $6 \mathrm{~km}$ below the sensor array. The LTBMS observatory is comprised of two main components: (1) downhole sensors and (2) a CORK head unit at the seafloor with a pressure and temperature multi-sensor package and data and power connections to the downhole instruments (Fig. 4). The CORK head assembly pressure sensor unit (PSU) is comprised of four pressure transducers, three of which are connected via two-way valves to individual hydraulic lines to one of three pressure ports downhole. The bottom-hole pressure port (\#3) was set below the Unit III/IV boundary to sample pore fluid pressure in the accretionary complex (Unit IV) beneath the Kumano forearc basin sediment (Units I-III). Pressure Port \#2 was located inside Unit III at 917 mbsf, just below the strainmeter sensing surface.

The downhole sensor suite comprises a strainmeter, a Guralp broadband seismometer, and a tilt combo (tiltmeter, geophone, accelerometer, and thermometer string digitizer) - all attached to a sensor carrier-and a thermistor string (Fig. 4). The strainmeter, along with the tilt combination package, was set into a fracture-free zone (890-917 mbsf) as identified via LWD drilling within the lower Unit III mudstone layer (Kopf et al., 2011a). This provides the strainmeter with the best possible coupling to a relatively homogenous section of the formation. Above the strainmeter is the instrument carrier (890-908 mbsf), hosting the seismometer and the tilt combo package. The sensor carrier also holds a data digitizer for the thermistor string, with the two uppermost nodes positioned in the screened casing interval and two nodes in the cemented section above the instrument carrier. 
It was necessary to isolate the seismic sensors from the possibility of signals being transmitted from the casing above by placing the 9 -inch casing shoe above the seismic sensor and cemented section. Therefore, the casing shoe was set at 888 mbsf (Fig. 3), above the top of the instrument carrier, in an interval without significant washouts. This ensures a good cementing zone for the bottom of the casing, which also serves to isolate the screened casing section from Unit III. The screened casing (757-780 mbsf) was set in a mudstone layer in Unit II to compare the pore fluid pressure in sedimentary layers with the accretionary prism in Unit IV. Finally, the swellable packer was set near the top of the screened casing interval to minimize the volume associated with the pressure measurement in pressure port \#3, and also set to ensure that the packer sealing surface $(\sim 1.5 \mathrm{~m})$ does not overlap with any casing joints.

The LTBMS CORK in Hole C0002G will provide a wealth of valuable data and observations once it is tied into the DONET seafloor cabled network.

\section{SmartPlug Data Set and GeniusPlug upgrade, Site C0010}

The full data set clearly shows a gradual increase in formation pressure and a subtle decrease in the seafloor reference pressure after installation but an overall increase in excess pore pressure. Regardless of this trend, three different types of transient pressure excursions were observed:

1. pressure pulses of up to several hundred pascals in sudden amplitude change relative to background that lasted for 20-60 minutes, which are largely associated with known teleseismic events;

2. tremor-like signals of a fraction of a kilopascal with durations of hours or even days, which can be associated with atmospheric and oceanographic events such as low-pressure systems, storm waves, and tsunamis; and

3. smaller individual pulses of low amplitude $(<1 \mathrm{kPa})$ that lasted for only minutes, which are tentatively associated with either low-magnitude deformational events in the accretionary complex or at the seafloor.

The data collected from the recovered SmartPlug (Fig. 5) prove to be a complete time series data set covering more than fifteen months (since deployment during Expedition 319 ), and they validate the concept of affordable, durable, replaceable CORK-like observatories (Kopf et al., 2011b). The upgraded version, the GeniusPlug (Fig. 5), is expandable; it uses an attached chamber ( $30 \mathrm{~cm}$ long) which can host other experiments-in the case of Expedition 332, a long-term geochemical and biological experiment.

\section{Post-Expedition 332 Work}

Two papers have been prepared, one focusing on vortex-induced vibration (VIV) mitigation for LTBMS deployment and the other on a preliminary analysis of the SmartPlug pressure and temperature data. These have been added to the proceedings for Expedition 332 (see details in Kitada et al., 2011 and in Kopf et al., 2011a, 2011b).

The LTBMS was due for a service call and hookup to battery source and data storage during the spring of 2011; however, these plans were postponed due to the Tohoku earthquake. The site was revisited during January 2012, and tests were successfully run on all systems. Again, the LTBMS was not hooked to the external power source, this time due to poor weather conditions. Current plans call for the system to be up and running after a remotely operated vehicle (ROV) visit in spring 2013.

\section{Plans for Future Experiments and Temporary Observatory Recovery}

In 2013, the LTBMS (Site C0002) will be hooked to the DONET network for real-time monitoring. The GeniusPlug (Site C0010) will need to be recovered before the geochemical and biological samples cycle through the system, particularly for sampling associated with the 11 March Tohoku earthquake. This is planned for the 2012/2013 NanTroSEIZE operations of D/V Chikyu. 


\section{Acknowledgements}

We thank all the crew of the D/V Chikyu and all the drilling operations and related personnel, particularly the efforts of the Marine Works Japan technicians and the Mantle Quest Japan onboard personnel who worked to make Expedition 332 such a success. We would also like to express our thanks to Tom Pettigrew of Pettigrew Engineering PLLC, who shared his considerable engineering experience with us.

\section{IODP Expedition 332 Scientific Party}

Sebastian Hammerschmidt, Toshinori Kimura, Kazuya Kitada, Rachel Lauer, Demian Saffer, and Geoff Wheat

\section{References}

Bangs, N.L.B., Moore, G.F., Gulick, S.P.S., Pangborn, E.M., Tobin, H.J., Kuramoto, S., and Taira, A., 2009. Broad, weak regions of the Nankai Megathrust and implications for shallow coseismic slip. Earth Planet. Sci. Lett., 284(1-2):44-49. doi:10.1016/j.epsl.2009.04.026

Kitada, K., Araki, E., Kimura, T., Kinoshita, M., Kopf, A., Hammerschmidt, S., Toczko, S., et.al., 2011. Drill pipe monitoring of vortex-induced vibration during IODP Expedition 332 observatory installations. In Kopf, A., Araki, E., Toczko, S., and the Expedition 332 Scientists, Proc. IODP, 332: Washington, DC (Integrated Ocean Drilling Program Management International, Inc.). doi:10.2204/iodp. proc.332.106.2011

Kodaira, S., Takahashi, N., Park, J.-O., Mochizuki, K., Shinohara, M., and Kimura, S., 2000. Western Nankai Trough seismogenic zone: Results from a wide-angle ocean bottom seismic survey. J. Geophys. Res., [Solid Earth], 105(B3):5887-5905. doi:10.1029/1999JB900394

Kopf, A., Araki, E., Toczko, S., and the Expedition 332 Scientists, 2011a. NanTroSEIZE Stage 2: Riserless Observatory. Proc. IODP, 332: Washington, DC (Integrated Ocean Drilling Program Management International, Inc.). doi:10.2204/ iodp.proc.332.2011

Kopf, A., Saffer, D.M., Davis, E.E., Hammerschmidt, S., LaBonte, A., Meldrum, R., Toczko, S., et.al., 2011b. The SmartPlug and GeniusPlug: Simple retrievable observatory systems for NanTroSEIZE borehole monitoring. In Kopf, A., Araki, E., Toczko, S., and the Expedition 332 Scientists, Proc. IODP, 332: Washington, DC (Integrated Ocean Drilling Program Management International, Inc.). doi:10.2204/iodp. proc.332.105.2011

McNeill, L., Saffer, D., Byrne, T., Araki, E., Toczko, S., Eguchi, N., Takahashi, K., and IODP Expedition 319 Scientists, 2010. IODP Expedition 319, NanTroSEIZE Stage 2: First IODP riser drilling operations and observatory installation towards understanding subduction zone seismogenesis. Sci. Drill., 10:4-12, doi: 10.2204/iodp.sd.10.01.2010

Miyazaki, S., and Heki, K., 2001. Crustal velocity field of southwest Japan: Subduction and arc-arc collision. J. Geophys. Res., [Solid Earth], 106(B3):4305-4326. doi:10.1029/2000 JB900312
Moore, G.F., Bangs, N.L., Taira, A., Kuramoto, S., Pangborn, E., and Tobin, H.J., 2007. Three-dimensional splay fault geometry and implications for tsunami generation. Science, 318(5853):1128-1131. doi:10.1126/science. 1147195

Moore, G.F., Park, J.-O., Bangs, N.L., Gulick, S.P., Tobin, H.J., Nakamura, Y., Sato, S., et.al., 2009. Structural and seismic stratigraphic framework of the NanTroSEIZE Stage 1 transect. In Kinoshita, M., Tobin, H., Ashi, J., Kimura, G., Lallemant, S., Screaton, E.J., Curewitz, D., Masago, H., Moe, K.T., and the Expedition 314/315/316 Scientists, Proc. IODP, 314/315/316: Washington, DC (Integrated Ocean Drilling Program Management International, Inc.). doi:10.2204/iodp.proc.314315316.102.2009

Moore, G.F., Taira, A., Klaus, A., et al., 2001. Proc. ODP, Init. Repts., 190: College Station, TX (Ocean Drilling Program). doi:10.2973/odp.proc.ir.190.2001

Park, J.-O., Tsuru, T., Kodaira, S., Cummins, P.R., and Kaneda, Y., 2002. Splay fault branching along the Nankai subduction zone. Science, 297(5584):1157-1160. doi:10.1126/ science. 1074111

Saffer, D., McNeill, L., Byrne, T., Araki, E., Toczko, S., Eguchi, N., Takahashi, K., and the Expedition 319 Scientists, 2010. NanTroSEIZE Stage 2: NanTroSEIZE riser/riserless observatory. Proc. IODP, 319: Washington, DC (Integrated Ocean Drilling Program Management International, Inc.). doi:10.2204/iodp.proc.319.2010

Seno, T., Stein, S., and Gripp, A.E., 1993. A model for the motion of the Philippine Sea Plate consistent with NUVEL-1 and geological data. J. Geophys. Res., [Solid Earth], 98(B10):1794117948. doi:10.1029/93JB00782

Strasser, M., Moore, G.F., Kimura, G., Kitamura, Y., Kopf, A.J., Lallemant, S., Park, J.-O., et al., 2009. Origin and evolution of a splay fault in the Nankai accretionary wedge. Nature Geosci., 2(9):648-652. doi:10.1038/ngeo609

Tobin, H.J., and Kinoshita, M., 2006. NanTroSEIZE: The IODP Nankai Trough Seismogenic Zone Experiment. Sci. Drill., 2:23-27. doi:10.2204/iodp.sd.2.06.2006

Wang, K., and Hu, Y., 2006. Accretionary prisms in subduction earthquake cycles: The theory of dynamic Coulomb wedge. $J$. Geophys. Res., 111(B6):B06410. doi:10.1029/2005JB004094

\section{Authors}

Sean T. Toczko, Center for Deep Earth Exploration (CDEX), Japan Agency for Marine-Earth Science and Technology (JAMSTEC), Yokohama Institute for Earth Sciences, 317325 Showa-machi, Kanazawa-ku, Yokohama, Kanagawa 2360001 Japan, e-mail: sean.jamstec@gmail.com

Achim J. Kopf, MARUM and Department of Geosciences, University of Bremen, 28359 Bremen, Germany, e-mail: akopf@uni-bremen.de

Eiichiro Araki, Institute for Research on Earth Evolution, Japan Agency for Marine-Earth Science and Technology (JAMSTEC), 2-15 Natsushima-cho, Yokosuka, Kanagawa 237-0061 Japan

\section{and the IODP Expedition 332 Scientific Party}

